\title{
Body composition in patients with Crohn's disease and ulcerative colitis
}

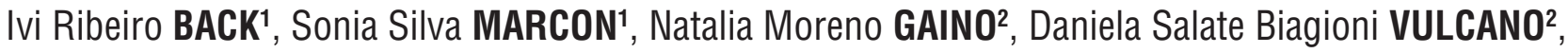 \\ Mariana de Souza DORNA² and Ligia Yukie SASSAKI ${ }^{2}$
}

Received 15/6/2016 Accepted 28/11/2016

\begin{abstract}
Background - The nutritional status of individuals with inflammatory bowel diseases is directly related to the severity of the disease and is associated with poor prognosis and the deterioration of immune competence. Objective - To assess the nutritional status and the body composition of outpatients with inflammatory bowel diseases. Methods - A cross-sectional study was conducted with clinical and nutritional assessment of patients with Crohn's disease and ulcerative colitis. Patients were classified according to the clinical activity through Crohn's Disease Activity Index and Mayo Score. Nutritional assessment consisted of anthropometric measurements of current weight, height, mid-arm circumference, triceps skinfold thickness and thickness of adductor policis muscle, with subsequent calculation of BMI, arm muscle circumference and the mid-arm muscle area (MAMA). The phase angle $(\mathrm{PhA})$ and lean and fat mass were obtained with the use of electrical bioimpedance. Descriptive statistics, chi-square test or Fisher exact test, ANOVA and $t$-test. Results - We evaluated 141 patients of which $54(38.29 \%)$ had Crohn's disease and $87(61.70 \%)$ ulcerative colitis. The mean age was $43.98( \pm 15.68)$ years in Crohn's disease and $44.28( \pm 16.29)$ years for ulcerative colitis. Most of the patients were in clinical remission of the disease (Crohn's disease: $88.89 \%$; ulcerative colitis: 87.36\%). Regarding the nutritional classification using BMI, it was found that $48.15 \%$ of Crohn's disease patients were eutrophic and $40.74 \%$ were overweight or obese; among patients with ulcerative colitis, $52.87 \%$ were classified as overweight or obese. When considering the triceps skinfold, it was observed in both groups a high percentage of overweight and obesity (Crohn's disease: $75.93 \%$; ulcerative colitis: $72.42 \%$ ). Crohn's disease patients showed the most affected nutritional status according to the nutritional variables when compared to patients with ulcerative colitis (BMI: $24.88 \mathrm{~kg} / \mathrm{m}^{2}$ x BMI: $26.56 \mathrm{~kg} / \mathrm{m}^{2}, P=0.054 ;$ MAMA: $35.11 \mathrm{~mm}$ x MAMA: $40.39 \mathrm{~mm}, P=0.040 ;$ PhA: $6.46^{\circ}$ $\mathrm{x}$ PhA: $6.83^{\circ}, P=0.006$ ). Conclusion - Patients with inflammatory bowel diseases have a high prevalence of overweight and obesity. Crohn's disease patients had more impaired anthropometric and body composition indicators when compared to patients with ulcerative colitis.
\end{abstract}

HEADINGS - Inflammatory bowel diseases. Crohn's disease. Ulcerative colitis. Body composition. Nutritional assessment.

\section{INTRODUCTION}

Inflammatory bowel disease (IBD), including Crohn's disease (CD) and ulcerative colitis (UC), consists in a chronic inflammatory disorder of the gut with intestinal and systemic manifestations. The principal symptoms are diarrhea, abdominal pain, gastrointestinal bleeding, weight loss, malnutrition and fatigue. According to United States estimates for $\mathrm{CD}$, incidence varies between 6 and 8 per 100,000 inhabitants, with a prevalence of 100 to 200 per 100,000 inhabitants. In the case of $\mathrm{UC}$, the incidence in that country ranges between 9 and 12, with a prevalence of 205 to 240 per 100,000 inhabitants ${ }^{(15,17,22)}$. Studies have shown higher rates of incidence of IBD in developing countries, including Brazil ${ }^{(8,34,38)}$.

Inflammatory state can lead to impaired nutritional status of patients with IBD. Undernutrition is a major complication among these patients and it is strongly associated with worst prognostic and increased risk of clinical and surgical complications ${ }^{(26)}$. Its prevalence may vary from $23 \%$ in outpatient units to $85 \%$ in hospitalized subjects ${ }^{(8,29)}$. Factors associated with undernutrition in these patients are inadequate food intake, chronic inflammatory state with increased energy requirements and losses from the gastrointestinal tract ${ }^{(8,26)}$.

On the other hand, the prevalence of overweight and obesity is increasing among these patients, especially in the last decades ${ }^{(7)}$.
Changes in dietary patterns is pointed out as one of the factors causing cardiovascular diseases and, therefore, this population needs careful nutritional follow-up in order to precociously detect patients that are under nutritional risk.

Because of the abovementioned reasons, nutritional assessment is a key point to the management of IBD patients. The aim of the present study was to evaluate the nutritional status and to evaluate body composition of IBD outpatients.

\section{METHODS}

\section{Subjects}

A cross-sectional study was performed on outpatients with either CD or UC from March through December 2012. The diagnosis was based on conventional clinical, endoscopic, radiologic and histological criteria ${ }^{(25)}$. Criteria for inclusion were age above 18 years and confirmed diagnosis of IBD. Criteria for exclusion were pregnancy, use of nutritional supplements, chronic diseases such as hepatitis B and C, HIV, chronic kidney disease, heart failure and refusal to participate in the study. The study was approved by the Research Ethics Committee of Botucatu Medical School, Sao Paulo State University (protocol \# 4178/2012), and a written informed consent was signed by all subjects before their inclusion.

Declared conflict of interest of all authors: none

Disclosure of funding: no funding received

Universidade Estadual de Maringá, PR, Brasil; ${ }^{2}$ Universidade Estadual Paulista (Unesp), Faculdade de Medicina, Botucatu, SP, Brasi .

Correspondence: Mariana de Souza Dorna. Departamento de Clínica Médica, Faculdade de Medicina, Universidade Estadual Paulista Júlio de Mesquita Filho. Campus de Botucatu. Av. Prof.

Montenegro s/n - CEP: 18618-970 - Botucatu, SP, Brasil. E-mail: mari_dorna@yahoo.com.br 


\section{Clinical assessment}

Patients were evaluated in accordance to the clinical course of the disease. The Crohn's Disease Activity Index (CDAI) was used to assess the disease activity of CD patients ${ }^{(3)}$. The Montreal Classification was used to classify the disease according to the age of appearance, disease location and presence of complications such as stricture, fistula or perianal disease ${ }^{(32)}$

Mayo score was used to assess the clinical activity of UC patients ${ }^{(30)}$. To determine the extent of intestinal damage (distal colitis, left-sided colitis or pancolitis), retrospective data from the first diagnostic colonoscopy were used.

\section{Anthropometric measurements}

Nutritional assessment was performed using anthropometric measurements and body composition analysis. All of them were conducted by the sane dietitian. Nutritional assessment included collection of the following information: weight, height, body mass index (BMI), Mid-arm Circumference (MAC), Triceps Skinfold Thickness (TSF), Mid-Arm Muscle Circumference (MAMC), Midarm Muscle Area (MAMA) and Adductor Policis Muscle (APM).

The BMI and MAMC were classified according to World Health Organization ${ }^{(39)}$ Lipschitz $^{(20)}$ and Frisancho ${ }^{(10)}$. The APM was measured according to Lameu et al. ${ }^{(19)}$. The percentages of adequation of MAC, TSF, and MAMC were classified as previously described Blackburn; Harvey ${ }^{(5)}$, Frisancho ${ }^{(11)}$, Harrison ${ }^{(13)}$, Lameu et al. ${ }^{(19)}$. The anthropometric measurements were taken in the morning, after the patients' clinical evaluation.

\section{Body composition analysis}

Bioelectrical impedance analysis (BIA) was measured using a tetrapolar and single-frequency equipment (Biodynamic-450, 800 $\mu \mathrm{A} ; 50 \mathrm{kHz}$ ) and applied to the skin using adhesive electrodes with the subject lying supine. Phase angle (PhA) derived from BIA was determined as previously discussed ${ }^{(18)}$ and its values were calculated as follows: $\mathrm{PhA}=$ arc tangent reactance/resistance $\mathrm{x}\left(180^{\circ} / \pi\right)^{(9)}$.

Fat-free mass (FFM) and fat mass (FM) were recorded according to the parameters given by the device. The values obtained were compared with values obtained for the healthy population ${ }^{(31)}$ according to percentile, sex and age. Evaluations of bioelectrical impedance analysis were standardized according to $\operatorname{Mattar}^{(23)}$ and Heyward Stolarrczyk ${ }^{(16)}$.

\section{Laboratory tests}

Blood samples were routinely drown in order to evaluate hematocrit values, hemoglobin, total protein and albumin, C-reactive protein and erythrocyte sedimentation rate. All determinations followed standardized laboratory techniques.

\section{Statistical analysis}

Descriptive statistics were performed. Frequencies and percentages were used for qualitative variables and means and respective standard deviations were calculated for quantitative variables. Chisquare $\left(\mathrm{X}^{2}\right)$ tests were applied to investigate the association between $\mathrm{CD}$ and $\mathrm{UC}$ and the demographic variables, outcomes, medication and nutritional parameters. Fisher's exact test was used when the expected values were lower than five, with a statistically significant association when $P \leq 0.05$. In order to compare $\mathrm{DC}$ and $\mathrm{UC}$ with nutritional parameters, ANOVAs were carried out. The $t$-test was used to compare the groups for the variables with normal distribution. $P$ value $<0.05$ was considered statistically significant. Statisti$\mathrm{cal}$ analysis were performed using SAS for Windows (version 9.1).

\section{RESULTS}

One hundred and forty-one patients were evaluated from March to December 2012. Among these, 54 (38.29\%) had CD and $87(61.70 \%)$ had UC.

\section{Sample description}

With respect to Crohn's disease, the average age of patients was $43.98( \pm 15.68)$ years and $59.26 \%$ were female. The majority of patients were in clinical remission of the disease, according to the CDAI. According to the Montreal classification, most of patients had complications of the disease, such as stenosing behavior (48.15\%), penetrating behavior $(27.78 \%)$ or perianal disease $(40.74 \%)$.

Regarding UC, the average age of the patients was 44.28 $( \pm 16.29)$ years and $55.17 \%$ were women. Among these, $83.92 \%$ were in clinical remission according to the Mayo score. Regarding the extent of the disease, $45.98 \%$ had pancolitis, $31.03 \%$ had distal colitis and $22.99 \%$ had left-sided colitis.

\section{Nutritional status and body composition of patients with Crohn's disease in contrast with patients with ulcerative colitis}

The comparative analysis of nutritional status and body composition of patients with $\mathrm{CD}$ and $\mathrm{UC}$ found that patients with $\mathrm{CD}$ have characteristics typical of more impaired nutritional status when compared to patients with UC, as well as increased inflammatory activity evaluated by means of laboratory tests such as CRP and ESR (Table 1). Lower BMI, MAMC, MAMA ( $P=0.04)$, APM, lean body mass index $(P=0.03)$, phase angle $(P=0.006)$ and laboratory tests such as hematocrit $(P=0.01)$ were verified in patients with $C D$.

TABLE 1. Comparative analysis of nutritional and laboratory parameters of patients with Crohn's disease (CD) and ulcerative colitis (UC)

\begin{tabular}{|c|c|c|c|}
\hline $\begin{array}{l}\text { Variables } \\
(n=141)\end{array}$ & $\begin{array}{l}\text { CD (n=54) } \\
\text { Mean (MD) }\end{array}$ & $\begin{array}{l}\text { UC ( } n=87) \\
\text { Mean (MD) }\end{array}$ & $P$-value \\
\hline Average age (years old) & $43.981( \pm 15.68)$ & $44.28( \pm 16.29)$ & 0.91 \\
\hline \multicolumn{4}{|l|}{ Anthropometry } \\
\hline BMI $\left(\mathrm{kg} / \mathrm{m}^{2}\right)$ & $24.88( \pm 4.70)$ & $26.56( \pm 5.16)$ & 0.054 \\
\hline MAC (c & $29.74( \pm 4.29)$ & $30.38( \pm 4.28)$ & 0.39 \\
\hline TSF $(\mathrm{m}$ & $21.68(=$ & 19.83 & 0.25 \\
\hline & $90.64( \pm 13.43)$ & $95.46( \pm 14.71)$ & 0.052 \\
\hline MAMA ( & $35.11( \pm 11.99)$ & $40.39( \pm 16.20)$ & 0.040 \\
\hline $\operatorname{APM}(\%)$ & $105.12( \pm 46.32)$ & $118( \pm 55.93)$ & 0.16 \\
\hline \multicolumn{4}{|l|}{ Body composition } \\
\hline $\operatorname{PhA}\left(^{\circ}\right)$ & $6.46( \pm 0.76)$ & $6.83( \pm 0.80)$ & 0.006 \\
\hline LM $(\%)$ & 71.8 & 71. & 0 . \\
\hline & ) & 29. & 0.5 \\
\hline LBMI $(\mathrm{kg} / \mathrm{m}$ & $17.61( \pm 2.74)$ & 18.65( & 0.03 \\
\hline FBMI $\left(\mathrm{kg} / \mathrm{m}^{2}\right)$ & $7.23( \pm 2.99)$ & $7.93( \pm 3.29)$ & 0.20 \\
\hline \multicolumn{4}{|l|}{ Laboratory tests } \\
\hline $\mathrm{Hb}(\mathrm{g} / \mathrm{dL})$ & $13.10( \pm 2.04)$ & $13.85( \pm 2.10)$ & 0.055 \\
\hline $\mathrm{Ht}(\%)$ & 39.6 & & \\
\hline $\mathrm{TF}$ & .71) & 7.3 & 0.96 \\
\hline $\mathrm{Alb}(\mathrm{g} / \mathrm{c}$ & $4.01( \pm 0.58)$ & $4.14( \pm 0.63)$ & 0.26 \\
\hline $\mathrm{CRP}(\mathrm{m}$ & $3.28( \pm 5.42)$ & $2.02( \pm 3.16)$ & 0.12 \\
\hline $\operatorname{ESR}(\mathrm{mm} / \mathrm{h})$ & $26.45( \pm 16.66)$ & $18.05( \pm 17.96)$ & 0.012 \\
\hline \multicolumn{4}{|c|}{$\begin{array}{l}\text { BMI: body mass index; MAC: mid-arm circumference; cm: centimeters; TSF: triceps skinfold } \\
\text { thickness; mm: millimeters; MAMC: mid-arm muscle circumference; MAMA: mid-arm } \\
\text { muscle area; APM: thickness of the adductor pollicis muscle; PhA: phase angle; LM: lean } \\
\text { mass; FM: fat mass; LBMI: lean body mass index; FBMI: fat body mass index; kg: kilogram; } \\
\text { Hb: hemoglobin; Ht: hematocrit; TP: total protein; Alb: albumin; CRP: C-reactive protein; } \\
\text { ESR: erythrocyte sedimentation rate. }\end{array}$} \\
\hline
\end{tabular}


On the classification of nutritional status, the body mass index (BMI) analysis showed that $11.11 \%$ CD patients had low weight, $48.15 \%$ were eutrophic and $40.74 \%$ were overweight and obese. In the case of patients with UC, $6.90 \%$ were underweight, $40.23 \%$ were eutrophic and $52.87 \%$ were overweight and obese (Table 2). Regarding the classification of nutritional status according to the Mid-arm circumference (\% MAC) and the Mid-Arm Muscle Circumference ( $\%$ MAMC), it was observed that most patients in both groups were eutrophic (Table 2).

TABLE 2. Nutritional status classification by body mass index (BMI), mid-arm circumference (MAC), triceps skinfold thickness (TSF), mid-arm muscle circumference (MAMC), mid-arm muscle area (MAMA) and thickness of adductor policis muscle (APM) of patients with Crohn's disease and ulcerative colitis

\begin{tabular}{lccc}
\hline Variables & $\begin{array}{c}\text { Crohn's } \\
\text { disease } \\
(\mathbf{n}=54)\end{array}$ & $\begin{array}{c}\text { Ulcerative } \\
\text { colitis } \\
(\mathbf{n}=87)\end{array}$ & $\boldsymbol{P}$-value \\
\hline BMI classification (\%) & & & 0.5304 \\
Low weight, n (\%) & $6(11.11)$ & $6(6.90)$ & \\
Eutrophic, n (\%) & $26(48.15)$ & $35(40.23)$ & \\
Overweight, n (\%) & $15(27.78)$ & $32(36.78)$ & \\
Obesity, n (\%) & $7(12.96)$ & $14(16.09)$ &
\end{tabular}

MAC classification (\%)

0.7949

Severe malnutrition, $\mathrm{n}(\%) \quad 1(1.85)$

Moderate malnutrition, $\mathrm{n}(\%) \quad 2(3.70) \quad 5(5.75)$

Mild malnutrition, $\mathrm{n}(\%) \quad 9(16.67) \quad 8(9.20)$

Eutrophic, n (\%) $30(55.56) \quad 52(79.77)$

Overweight, $\mathrm{n}(\%) \quad 8(14.81) \quad 12(13.79)$

Obese

$4(7.41) \quad 9(10.34)$

TSF classification (\%)

Severe malnutrition, $\mathrm{n}(\%) \quad 3(5.56)$

Moderate malnutrition, $\mathrm{n}(\%) \quad 2(3.70) \quad 4(4.60)$

Mild malnutrition, n (\%) 7 (12.96) $9(10.34)$

Eutrophic, n (\%) $1(1.85) \quad 5(5.75)$

Overweight, n (\%) $\quad 3(5.56) \quad 4(4.60)$

Obese, n (\%) $\quad 38(70.37) \quad 59(67.82)$

MAMC classification (\%)

Severe malnutrition, $\mathrm{n}(\%) \quad 5(9.26) \quad 2(2.30)$

Moderate malnutrition, $\mathrm{n}(\%) \quad 7(12.96) \quad 9(10.34)$

Mild malnutrition, $\mathrm{n}(\%) \quad 13(24.07) \quad 21(24.14)$

Eutrophic, n (\%) 29(53.70) $50(57.47)$

Obese, n (\%)

$0.00 \quad 5(5.75)$

MAMA classification (\%)

Moderate/Mild malnutrition 13 (24.07) 13 (15.12)

Eutrophic

$31(57.41) \quad 67(77.91)$

\begin{tabular}{lcc} 
APM classification (\%) & & 0.2516 \\
No depletion, $\mathrm{n}(\%)$ & $23(43.40)$ & $49(57.65)$ \\
Depletion light, $\mathrm{n}(\%)$ & $9(16.98)$ & $7(8.24)$ \\
Moderate depletion, $\mathrm{n}(\%)$ & $9(16.98)$ & $15(17.65)$ \\
Severe depletion, $\mathrm{n}(\%)$ & $12(22.64)$ & $14(16.47)$ \\
\hline
\end{tabular}

BMI: body mass index; MAC: mid-arm circumference; TSF: triceps skinfold thickness; MAMC: mid-arm muscle circumference; MAMA: mid-arm muscle area; APM: thickness of the adductor pollicis muscle.

0.0261
In relation to the nutritional status by the parameter Triceps Skinfold Thickness (TSF\%), a high percentage of obesity was observed in both groups and a small portion was classified as malnourished (Table 2). It was also observed, according to the Mid-Arm Muscle Area, that 42.59\% CD patients were under mild, moderate or severe malnutrition and $22.10 \%$ patients with UC were under mild, moderate or severe malnutrition. According to the classification of nutritional status by the Thickness of Adductor Policis Muscle (APM), 22.64\% CD patients had severe muscle depletion, while $16.47 \%$ patients with UC had this condition (Table 2).

\section{Nutritional status and body composition of patients with Crohn's disease in activity contrasted to patients in clinical remission}

When comparing patients with active $\mathrm{CD}$ and patients in clinical remission (Table 3 ), it was found that patients with the active disease were younger than patients in remission $(P=0.008)$. Patients in clinical activity were observed to have lower averages of anthropometric variables, as observed for BMI $(P<0.001)$, MAC $(P=0.01), \operatorname{MAMC}(P=0.04)$ and APM $(P=0.009)$.

TABLE3. Anthropometric analysis, body composition and laboratory parameters of patients with Crohn's disease in activity and in clinical remission

\begin{tabular}{lccc}
\hline \multicolumn{4}{c}{ Crohn's disease } \\
Variables & $\begin{array}{c}\text { Activity } \\
\mathbf{n}=\mathbf{2 4}\end{array}$ & $\begin{array}{c}\text { Remission } \\
\mathbf{n}=30\end{array}$ & $\boldsymbol{P}$-value \\
\hline Age (years old) & $37.83( \pm 12.81)$ & $48.90( \pm 16.21)$ & 0.008 \\
Female gender, n (\%) & $16.00(66.67)$ & $16.00(53.33)$ & 0.3218
\end{tabular}

Anthropometry

$\begin{array}{lccc}\text { BMI }\left(\mathrm{kg} / \mathrm{m}^{2}\right) & 22.66( \pm 4.32) & 26.66( \pm 4.28) & 0.001 \\ \text { MAC }(\mathrm{cm}) & 28.12( \pm 3.85) & 31.03( \pm 4.24) & 0.01 \\ \text { TSF }(\mathrm{mm}) & 19.83( \pm 9.76) & 23.16( \pm 10.36) & 0.23 \\ \text { MAMC }(\%) & 86.55( \pm 12.21) & 93.92( \pm 13.65) & 0.043 \\ \text { MAMA }\left(\mathrm{cm}^{2}\right) & 31.84( \pm 10.74) & 37.74( \pm 12.45) & 0.07 \\ \text { APM }(\%) & 86.54( \pm 37.87) & 119.36( \pm 47.70) & 0.009\end{array}$

$0.1561 \quad$ Body composition

$\begin{array}{lccc}\operatorname{PhA}\left({ }^{\circ}\right) & 6.42( \pm 0.73) & 6.49( \pm 0.79) & 0.75 \\ \operatorname{LM}(\%) & 73.86( \pm 9.26) & 70.15( \pm 7.57) & 0.11 \\ \text { FM }(\%) & 26.13( \pm 9.26) & 29.84( \pm 7.57) & 0.11 \\ \text { LBMI }\left(\mathrm{kg} / \mathrm{m}^{2}\right) & 16.45( \pm 2.21) & 18.54( \pm 2.80) & 0.004 \\ \text { FBMI }\left(\mathrm{kg} / \mathrm{m}^{2}\right) & 6.21( \pm 2.82) & 8.05( \pm 2.90) & 0.02\end{array}$

Laboratory tests

$\begin{array}{lccc}\mathrm{Hb}(\mathrm{g} / \mathrm{dL}) & 12.36( \pm 2.22) & 13.76( \pm 1.63) & 0.01 \\ \mathrm{Ht}(\%) & 37.77( \pm 6.12) & 41.37( \pm 4.50) & 0.02 \\ \mathrm{TP}(\mathrm{g} / \mathrm{dL}) & 7.48( \pm 0.81) & 7.28( \pm 0.62) & 0.36 \\ \mathrm{Alb}(\mathrm{g} / \mathrm{dL}) & 3.93( \pm 0.74) & 4.08( \pm 0.36) & 0.34 \\ \mathrm{CRP}(\mathrm{mg} / \mathrm{dL}) & 4.06( \pm 6.27) & 2.64( \pm 4.63) & 0.39 \\ \mathrm{ESR}(\mathrm{mm} / \mathrm{h}) & 30.81( \pm 19.14) & 22.61( \pm 13.36) & 0.09\end{array}$

BMI: body mass index; MAC: mid-arm circumference; TSF: triceps skinfold thickness; MAMC: mid-arm muscle circumference; MAMA: mid-arm muscle area; APM: thickness of the adductor pollicis muscle; PhA: phase angle; LM: lean mass; FM: fat mass; LBMI: lean body mass index; FBMI: fat body mass index; Hb: hemoglobin; Ht: hematocrit; TP: total protein; Alb: albumin; CRP: C-reactive protein; ESR: erythrocyte sedimentation rate. 


\section{Nutritional status and body composition of patients with ulcerative colitis in activity contrasted to patients in clinical remission}

Patients with active disease were younger than patients in remission $(P=0.01)$. Regarding the anthropometric variables, lower averages in patients in clinical activity were observed, as showed BMI $(P=0.01)$, MAC $(P=0.001)$, MAMC $\%(P=0.01)$ and $\operatorname{MAMA}(P=0.02)$. Regarding the evaluation of body composition, significant differences were found between patients in activity and patients in remission as the $\% \mathrm{LM}(P=0.01), \% \mathrm{FM}(P=0.01)$ and FBMI $(P=0.009)$ (Table 4).

TABLE 4. Anthropometric analysis. body composition and laboratory parameters of patients with ulcerative colitis in activity and in clinical remission

\begin{tabular}{|c|c|c|c|}
\hline \multirow[b]{2}{*}{ Variables } & \multicolumn{2}{|c|}{ Ulcerative colitis } & \multirow[b]{2}{*}{$P$-value } \\
\hline & $\begin{array}{c}\text { Activity } \\
n=21\end{array}$ & $\begin{array}{c}\text { Remission } \\
\mathrm{n}=66\end{array}$ & \\
\hline Age (years old) & $36.42( \pm 15.59)$ & $46.78( \pm 15.81)$ & 0.01 \\
\hline Female gender, n $(\%)$ & $11.00(52.38)$ & $37.00(56.06)$ & 0.7677 \\
\hline \multicolumn{4}{|l|}{ Anthropometry } \\
\hline BMI $\left(\mathrm{kg} / \mathrm{m}^{2}\right)$ & $24.28( \pm 4.21)$ & $27.28( \pm 5.25)$ & 0.01 \\
\hline $\mathrm{MAC}(\mathrm{cm})$ & $27.86( \pm 4.92)$ & $31.18( \pm 3.75)$ & 0.001 \\
\hline $\mathrm{TSF}(\mathrm{mm})$ & $17.28( \pm 7.77)$ & $20.64( \pm 8.97)$ & 0.12 \\
\hline MAMC (\%) & $88.67( \pm 17.47)$ & $97.62( \pm 13.14)$ & 0.01 \\
\hline $\operatorname{MAMA}\left(\mathrm{cm}^{2}\right)$ & $33.41( \pm 15.05)$ & $42.61( \pm 16.03)$ & 0.02 \\
\hline $\operatorname{APM}(\%)$ & $108.04( \pm 44.11)$ & $121.06( \pm 59.06)$ & 0.36 \\
\hline \multicolumn{4}{|l|}{ Body composition } \\
\hline $\operatorname{PhA}\left({ }^{\circ}\right)$ & $6.61( \pm 0.82)$ & $6.90( \pm 0.78)$ & 0.14 \\
\hline $\mathrm{LM}(\%)$ & $74.51( \pm 7.38)$ & $69.88( \pm 6.94)$ & 0.01 \\
\hline $\mathrm{FM}(\%)$ & $25.48( \pm 7.38)$ & $30.11( \pm 6.94)$ & 0.01 \\
\hline $\operatorname{LBMI}\left(\mathrm{kg} / \mathrm{m}^{2}\right)$ & $17.98( \pm 2.80)$ & $18.87( \pm 2.75)$ & 0.20 \\
\hline FBMI $\left(\mathrm{kg} / \mathrm{m}^{2}\right)$ & $6.32( \pm 2.50)$ & $8.45( \pm 3.36)$ & 0.009 \\
\hline \multicolumn{4}{|l|}{ Laboratory tests } \\
\hline $\mathrm{Hb}(\mathrm{g} / \mathrm{dL})$ & $12.82( \pm 3.09)$ & $14.21( \pm 1.51)$ & 0.01 \\
\hline $\mathrm{Ht}(\%)$ & $39.91( \pm 6.66)$ & $42.82( \pm 4.02)$ & 0.02 \\
\hline TP (g/dL) & $7.23( \pm 0.94)$ & $7.42( \pm 1.16)$ & 0.59 \\
\hline Alb (g/dL) & $4.01( \pm 0.46)$ & $4.19( \pm 0.68)$ & 0.38 \\
\hline CRP (mg/dL) & $1.33( \pm 0.85)$ & $2.22( \pm 3.54)$ & 0.34 \\
\hline $\operatorname{ESR}(\mathrm{mm} / \mathrm{h})$ & $21.19( \pm 14.37)$ & $17.10( \pm 18.93)$ & 0.42 \\
\hline
\end{tabular}

BMI: body mass index; MAC: mid-arm circumference; TSF: triceps skinfold thickness; MAMC: mid-arm muscle circumference; MAMA: mid-arm muscle area; APM: thickness of the adductor pollicis muscle; PhA: phase angle; LM: lean mass; FM: fat mass; LBMI: lean body mass index; FBMI: fat body mass index; Hb: hemoglobin; Ht: hematocrit; TP: total protein; Alb: albumin; CRP: C-reactive protein; ESR: erythrocyte sedimentation rate.

\section{DISCUSSION}

Nutritional assessment is an important point for success in the management of patients with IBD because it can help identifying shortcomings or even nutritional excesses ${ }^{(24)}$. The first studies on nutritional assessment in IBD identified malnutrition as the main characteristic in these individuals ${ }^{(21)}$. Malnutrition may be the result of increased losses or malabsorption due to the extent of the bowel portion affected by the disease, surgical resections, fistula or other factors that determine the functional or anatomical reduction of intestinal absorptive surface and/or acceleration of intestinal transit ${ }^{(8,26)}$.
Low rates of malnutrition were found in the present study according to the BMI, and most of the patients were classified as eutrophic when they were evaluated by MAC, MAMC or MAMA. When evaluated by the APM, $43.40 \%$ of patients with CD and $57.65 \%$ of patients with UC were found without muscle depletion. This can be explained by the presence of a larger number of subjects in clinical remission and by the fact that the study was conducted with outpatients. However, we observed lower values of nutritional parameters such as BMI, MAC and MAMC in patients with active disease when compared with patients in clinical remission, for both CD and UC patients, probably due to the increased energy demand related to inflammation and lower food intake due to the symptoms of IBD.

We observed high rates of overweight and obesity among patients with CD and UC according to BMI, TSF and MAC. Obesity, once considered a rare condition in IBD, has become increasingly prevalent, mainly in the last two decades ${ }^{(2,7)}$. It is believed that this is related to increased number of comorbidities, such as diabetes, hypertension, thromboembolic disease, infections, $\operatorname{cancer}^{(7)}$. It is also associated with increased risk of complications such as advanced age at diagnosis, greater number of relapses of the disease, perianal disease incidence, more frequent hospitalizations $^{(6)}$ and postoperative complications, including wound infection and dehiscence of surgical anastomoses ${ }^{(35)}$. CD patients classified as overweight or obese (BMI $>25 \mathrm{~kg} / \mathrm{m}^{2}$ ) required surgical procedure for the treatment of the disease in earlier stage (24 months), as a result of complications, when compared to patients with low weight $\left(\mathrm{BMI}<18.5 \mathrm{~kg} / \mathrm{m}^{2}\right)(252 \mathrm{months})^{(14)}$. An observational study conducted in Scotland in 2009 found that $18 \%$ of study participants with IBD were considered obese $\left(\mathrm{BMI}>30 \mathrm{~kg} / \mathrm{m}^{2}\right)$ and there was a significantly higher number of obese patients with CD than with UC $(P=0.05)^{(35)}$. A previous study $^{(6)}$ reported earlier rates of $3 \%$ of obesity in DC, $32.4 \%$ of this population showing a $\mathrm{BMI} \geq 25 \mathrm{~kg} / \mathrm{m}^{2}$. Comparison of the data suggests a drastic change in BMI of patients from the studies, demonstrating an increase in the rate of obese patients, as it has been observed in the general population ${ }^{(35)}$.

Obesity is also a risk factor for developing cardiovascular diseases. Studies indicate an increased risk of developing cardiovascular disease in IBD patients as compared to non-IBD patients ${ }^{(12,28)}$, what is probably associated with chronic inflammation. A Danish cohort study comparing individuals with and without IBD found a significantly higher risk of ischemic heart disease in the first year after diagnosis of IBD in patients. Furthermore, higher risk was observed among women than among men $(P=0.03)$. A meta-analysis of nine studies observed an increase of $18 \%$ in the risk of stroke and ischemic heart disease in patients with IBD. The increased risk of stroke and ischemic heart disease was more prominent in females when compared to males, probably because of the inherent differences and non-modifiable risk factors ${ }^{(33)}$.

Recently, obesity itself has been studied as a potential risk factor for the development of $\mathrm{CD}^{(7)}$. In a case-control research that evaluated patients with $\mathrm{CD}, \mathrm{UC}$ and healthy controls, the authors found a significant association between the diagnosis of $\mathrm{CD}$ and obesity, even after adjusting for other known risk factors for the development of $\mathrm{CD}$, such as age, smoking history, family history of the disease and history of appendectomy ${ }^{(36)}$.

Nutritional assessment consists of evaluating the nutritional status and body composition. Body composition assessment done 
through anthropometric measurements and bioelectrical impedance analysis (BIA) are valuable tools to identify nutritional status due to its low cost and easy applicability ${ }^{(1,4,27)}$.It is worth noting that the gold standard method for assessing body composition is the Dual-Energy X-Ray Absorptiometry (DEXA), which allows direct and non-invasive measurement of bone mass, fat-free mass and fat mass. However, DEXA requires skilled personnel, has low affordability, high radiation exposure and it is considered a costly examination. In the present study, we used the BIA to assess body composition. Studies show good correlation between the parameters of body composition assessed by BIA and by DEXA ${ }^{(37)}$. The BIA is an inexpensive examination, noninvasive, easy to apply and does not use ionizing radiation. Furthermore, it provides the calculation of the phase angle, which is the parameter used with prognostic purposes in some chronic diseases.

We must emphasize the study participants should not be considered representative of the total population with IBD, once they come from a tertiary hospital with peculiar characteristics. Other limiting factors should be mentioned, as the sample size and the kind of design adopted (cross-sectional). Longitudinal studies with more patients are needed so that the real significance of the results is confirmed. Despite this need, nutritional guidance programs can already be adopted and encouraged with the aim of preventing or correcting nutritional deficits for the population under study.

\section{CONCLUSION}

In relation to nutritional status and body composition, it was found that patients with IBD showed high prevalence of overweight and obesity. The majority of the patients were in clinical remission. As for comparing the nutritional status among patients with $\mathrm{CD}$ and UC, it was found that patients with CD had anthropometric and body composition parameters more impaired than UC patients.

In spite of the limitations, the results of this study increase the knowledge about the importance of assessing the nutritional status of patients with Crohn's disease or ulcerative colitis and underscore the importance of the multidisciplinary team performance in the treatment centers.

\section{ACKNOWLEDGEMENTS}

This work was supported by CAPES (Coordenação de Aperfeiçoamento de Pessoal de Nível Superior).

\section{Authors' contributions}

Back IR: collected data and design of the manuscript. Marcon SS: critical revision. Gaino NM: collected data. Vulcano DSB: design of the manuscript. Dorna MS: design of the manuscript. Sassaki LY: conception and design of the manuscript.

Back IR, Marcon SS, Gaino NM, Vulcano DSB, Dorna MS, Sassaki LY. Composição corporal de pacientes com doença de Crohn e colite ulcerativa. Arq Gastroenterol. 2017;54(2):109-14.

RESUMO - Contexto - O estado nutricional de indivíduos com doença inflamatória intestinal está diretamente relacionado à gravidade da doença e associado a mau prognóstico e deterioração da competência imune. Objetivo - Avaliar o status e a composição corporal de pacientes ambulatoriais com doença inflamatória intestinal. Metódos - Foi conduzido um estudo transversal com avaliação clínica e nutricional de pacientes com doença de Crohn e colite ulcerativa. Pacientes foram classificados de acordo com o índice de atividade clínica Crohn's Disease Activity Index e escore de Mayo. Avaliação nutricional foi composta peso atual, estatura, circunferência do braço, dobra cutânea tricipital e espessura do músculo adutor do polegar. Posteriormente, foram calculados índice de massa corporal, circunferência muscular do braço e área muscular do braço corrigida. O ângulo de fase e massa magra e massa gorda foram derivadas da bioimpedância elétrica. Foram realizados análise descritiva, teste de qui-quadrado ou exato de Fisher, teste $t$ e ANOVA. Resultados - Foram avaliados 141 pacientes, sendo 54 (38,29\%) com doença de Crohn e $87(61,70 \%)$ com colite ulcerativa. A idade média foi de 43,98 $( \pm 15,68)$ anos em pacientes com doença de Crohn e 44,28 $( \pm 16,29)$ anos em pacientes com colite ulcerativa. A maioria dos pacientes estava em remissão clínica da doença (doença de Crohn: 88,89\%; colite ulcerativa: 87,36\%). O estado nutricional de acordo com o IMC foi $48,15 \%$ eutrófico e $40,74 \%$ sobrepeso/obesidade para doença de Crohn; entre os indivíduos com colite ulcerativa, 52,87\% foram classificados como sobrepeso/obesidade. Ao se considerar dobra cutânea do tríceps, observou-se obesidade em ambos os grupos (doença de Crohn 75,93\%; colite ulcerativa: 72,42\%). Pacientes com doença de Crohn apresentam maiores variações de composição corporal quando comparados com pacientes com colite ulcerativa (IMC: $24,88 \mathrm{~kg} / \mathrm{m}^{2}$ x IMC: $26,56 \mathrm{~kg} / \mathrm{m}^{2}, P=0,054$; área do músculo do braço: $35,11 \mathrm{~mm}$ x área do músculo do braço: 40,39 mm, $P=0,040$; ângulo de fase: $6,46^{\circ} \mathrm{x}$ ângulo de fase: $6,83^{\circ}, P=0,006$ ). Conclusão - Pacientes com doença inflamatória intestinal apresentaram alta prevalência de sobrepeso e obesidade. Indivíduos com doença de Crohn apresentaram parâmetros de composição corporal e de antropometria mais comprometidos, quando comparados com indivíduos com colite ulcerativa.

DESCRITORES - Doenças inflamatórias intestinais. Doença de Crohn. Colite ulcerativa. Composição corporal. Avaliação nutricional.

\section{REFERENCES}

1. Acuña K, Cruz T. Avaliação do Estado Nutricional de Adultos e Idosos e Situação Nutricional da População Brasileira. Arq Bras Endocrinol Metab. 2004;48:345-61

2. Andrade MIS, Maio R, Dourado KF, Macêdo PFC Barreto Neto AC. Excessive weight - muscle depletion paradox and cardiovascular risk factors in outpatients with inflammatory bowel disease. Arq Gastroenterol. 2015;52:37-45.

3. Best WR, Becktel JM, Singleton JW, Kern F Jr. Development of a Crohn's disease activity index. National Cooperative Crohn's Disease Study. Gastroenterology.1976;70:439-44.
4. Bin CM. Comparação entre Método Funcional com Avaliação Subjetiva Global, Antropometria, Inquérito Alimentar e Análise Bioquímica na Estimativa do Estado Nutricional de Pacientes com Doença de Crohn em Remissão Clínica. [Dissertation]. Universidade Federal do Rio Grande do Sul, Faculdade de Medicina, Porto Alegre, 2007.

5. Blackburn GL, Harvey KB. Nutritional assessment as a routine in clinical medicine. Postgraduate Medicine. 1982;71:46-63.

6. Blain A, Cattan S, Beaugerie L, Carbonnel F, Gendre JP, Cosnes J. Crohn's disease clinical course and severity in obese patients. Clin Nutr. 2002;21:51-7. 
7. Boutros M, Maron D. Inflammatory Bowel Disease in the Obese Patient. Clinics in Colonand Rectal Surgery. 2011;24:244-52.

8. Elia PP, Fogaça HS, Barros RG, Zaltman C, Elia CSC. Descriptive analysis of the social, clinical, laboratorial and anthropometric profiles of inflammatory bowel disease inwards patients from the "Clementino Fraga Filho" University Hospital, Rio de Janeiro, RJ, Brazil. Arq Gastroenterol. 2007:44:332-9.

9. Flora APL, Dichi I. Current aspects of nutritional therapy in inflammatory bowel disease. Rev Bras Nutr Clin. 2006;21:131-7.

10. Frisancho AR. Anthropometric standards for the assessment of growth andnutritional status. Michigan: University of Michigan;1990.

11. Frisancho AR. New norms of upper limb fat and muscle areas for assessment of nutritional status. Am J Clin Nutr. 1981;34:2540-5.

12. Gandhi S, Narula N, Marshall JK, Farkouh M. Are Patients with Inflammatory Bowel Disease at Increased Risk of Coronary Artery Disease? Am J Med. 2012;125:956-62.

13. Harrison GG, Buskirk ER, Lindsay Carter JE, Johnston FE, Lohman TG, Pollock ML. Skinfold thicknesses and measurement technique. In: Lohman TG, Roche AF, Martorell R. Anthropometric standardization reference manual. Champaign: Human Kinetics. 1988; p.55-70.

14. Hass DJ, Brensinger CM, Lewis JD, Lichtenstein GR. The impact of increased body mass index on the clinical course of Crohn's disease. Clin Gastroentero Hepatol. 2006;4:482-8.

15. Herrington LJ, Liu L, Lewis JD, Griffin PM, Allison J. Incidence and prevalence of inflammatory bowel disease in a Northern California managed care organization, 1996-2002. Am J Gastroenterol. 2008;103:1998-2006.

16. Heyward VV, Stolarczyk LM. Métodos de dobras cutâneas. In: Heyward VV, Stolarczyk LM. Avaliação da Composição Corporal aplicada: São Paulo Manole; 2000; 23-45.

17. Kappelman MD, Rifas-Shiman SL, Kleinman K, Ollendorf D, Bousvaros A, Grand RJ, Finkelstein JA. The prevalence and geographic distribution of Crohn's disease and ulcerative colitis in the United States. Clin Gastroenterol Hepatol. 2007;5:1424-9.

18. Kyle UG, Soundar EP, Genton L, Pichard C. Can phase angle determined by bioelectrical impedance analysis assess nutritional risk? A comparison between healthy and hospitalized subjects. Clin Nutr. 2012;31: 875-81.

19. Lameu EB, Gerude MF, Corrêa RC, Lima KA. Adductor policis muscle: a new anthropometric parameter. 2004;39:57-62.

20. Lipschitz DA. Screening for nutritional status in the elderly. Prim Care 1994;21:55-67.

21. Lochs, H. Basics in Clinical Nutrition: Nutritional support in inflammatory bowel disease. e-SPEN, the European e-Journal of Clinical Nutrition and Metabolism.2010; 8. p. 100-3.

22. Loftus CG, Lofus EV, Harmsen WS, Zinsmeister AR, Tremaine WJ, Melton LJ 3rd, Sandborn WJ. Update on the incidence and prevalence of Crohn's disease and ulcerative colitis in Olmsted County, Minnesota, 1940-2000. Inflamm Bowel Dis. 2007; 13:254-61

23. Mattar R. Avaliação da Composição Corporal por bioimpedância: uma nova perspectiva. Rev Âmbito Méd Desp. 1997.
24. Mijac DD, Janković GL, Jorga J, Krstić MN. Nutritional status in patients with active inflammatory bowel disease: Prevalence of malnutrition and methods for routine nutritional assessment. Eur J Intern Med. 2010;21:315-9.

25. O'Morain C, Tobin A, Leen E, Suzuki Y, O' Riordan T. Criteria of case definition in Crohn's disease and ulcerative colitis. Scand J Gastroenterol. 1989;170:7-11.

26. Rocha R, Santana GO, Almeida N, Lyra AC. Analysls of fat and muscle mass in patients with inflammatory bowel disease during remission and active phase. J Nutr. 2008;101:676-9.

27. Royall D, Greenberg GR, Allard JP, Baker JP, Harrison JE, Jeejeebhoy KN Critical assessment of body-composition measurements in malnourished subjects with Crohn's disease: the role of bioelectric impedance analysis. J Clin Nutr. 1994;59:325-30.

28. Rungoe C, Basit S, Ranthe MF, Wohlfahrt J, Langholz E, Jess T. Risk of ischaemic heart disease in patients with inflammatory bowel disease: a nationwide Danish cohort study. Gut. 2013;62:689-94.

29. Salviano FN, Burgos MGPA, Santos EC. Perfil socioeconômico e nutricional de pacientes com doença inflamatória intestinal internados em um hospital universitário. Arq. Gastroenterol. 2007;44:99-106.

30. Schroeder KW, Tremaine WJ, Ilstrup DM. Coated oral 5-aminosalicylicacid therapy for mildly to moderately active ulcerative colitis. A randomized study. N Engl J Med. 1987;317:1625-9.

31. Schutz Y, Kyle UUG, Pichard C. Fat-free mass index and fat mass index percentiles in Caucasians aged 18-98y. Int J Obes Relat Metab Disord. 2002; 26:953-60.

32. Silverberg MS, Satsangi J, Ahmad T, Arnott ID, Bernstein CN, Brant SR, et al. Toward an integrated clinical, molecular and serological classification of inflammatory bowel disease: Report of a Working Party of the 2005 Montreal World Congress of Gastroenterology. Can J Gastroenterol. 2005;Suppl A:5A-36A

33. Singh S, Singh H, Loftus EV Jr, Pardi DS. Risk of Cerebrovascular Accident and Ischemic Heart Disease in Patients with Inflammatory Bowel Disease: A Systematic Review and Meta-analysis. Clin Gastroenterol Hepatol. 2014;12:382-93.

34. Souza MH, Troncon LE, Rodrigues CM, Viana CF, Onof re PH, Monteiro RA, et al. Trends in the occurrence (1980-1999) and clinical features of Crohn's disease and ulcerative colitis in a university hospital in southeastern Brazil. Arq Gastroenterol. 2002;39:98-105.

35. Steed H, Walsh S, Reynolds N. A brief report of the epidemiology of obesity in the inflammatory bowel disease population of Tayside, Scotland. Obes Facts. 2009;2:370-2.

36. Suibhne TN, Raftery TC, McMahon O, Walsh C, O'Morain C, O'Sullivan M. High prevalence of overweight and obesity in adults with Crohn's disease: Associations with disease and lifestyle factors. J Crohns Colitis. 2013;7:241-8.

37. Thibault R, Genton L, Pichard C. Body composition: Why, when and for who? Clin Nutr. 2012;31:435-47.

38. Victoria CR, Sassaki LY, Nunes HRC. Incidence and prevalence rates of inflammatory bowel diseases, in Midwestern of São Paulo state, Brazil. Arc Gastroenterol. 2009;46:20-5.

39. World Health Organization. Obesity: preventing and managing the global epidemic. Geneva: WHO, 1998 (Reports of WHO). 